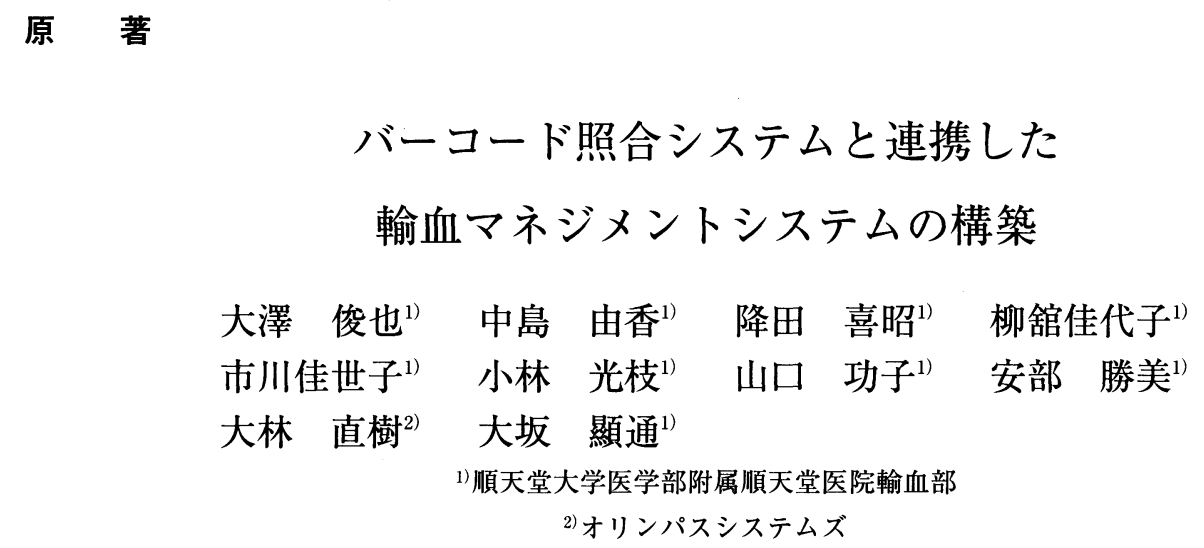

(平成 16 年 4 月 22 日受付)

(平成 16 年 8 月 25 日受理)

\title{
A BLOOD TRANSFUSION MANAGEMENT SYSTEM WHICH CONNECTS WITH THE BARCODE PATIENT-BLOOD UNIT IDENTIFICATION SYSTEM
}

\author{
Toshiya Ohsawa ${ }^{1)}$, Yuka Nakajima ${ }^{1)}$, Yoshiaki Furuta ${ }^{1)}$, Kayoko Yanagidate ${ }^{1)}$, \\ Kayoko Ichikawa $^{1)}$, Mitsue Kobayashi ${ }^{1)}$, Ioko Yamaguchi ${ }^{1)}$, Katsumi Abe ${ }^{1)}$, \\ Naoki Ohbayashi ${ }^{2)}$ and Akimichi Ohsaka ${ }^{1)}$ \\ ${ }^{1)}$ Department of Transfusion Medicine, Juntendo University Hospital, \\ Juntendo University School of Medicine \\ ${ }^{2)}$ Olympus Systems Corporation
}

To prevent incorrect blood transfusion attributable to misidentification of the patient or blood unit, we developed a novel computer-assisted blood transfusion management system which connects with the barcode patient-blood unit identification system. The system is composed of 1) a hand-held computer that reads the barcodes of the patient's wristband, the blood unit, the compatibility report form and the compatibility label attached to the blood pack, 2) a computer-assisted blood transfusion management system capable of receiving the patient's transfusion data from a bedside hand-held computer, and 3) an automated blood testing instrument (GelStation). This system permits a decrease in the number of manual procedures in multiple steps of the blood transfusion process and the monitoring of bedside verification procedures in real-time at the transfusion laboratory, together resulting in the minimization of human errors and the improvement of transfusion safety. Further evaluation is needed to establish whether this barcode patient-blood unit identification system may play a role in increasing transfusion safety.

Key words : patient-blood unit identification system, barcode, wristband, hand-held computer, realtime monitoring

\section{はじめに}

輸血医療におけるヒューマンエラーは $\mathrm{ABO}$ 血 液型不適合輸血（以下，不適合輸血）に直結する.
日本輸血学会 $\mathrm{ABO}$ 型不適合輸血事故調査および 対策チームの報告では, 不適合輸血発生原因の過 半数は血液バッグあるいは患者の「取り違え」で 
覧床检查部

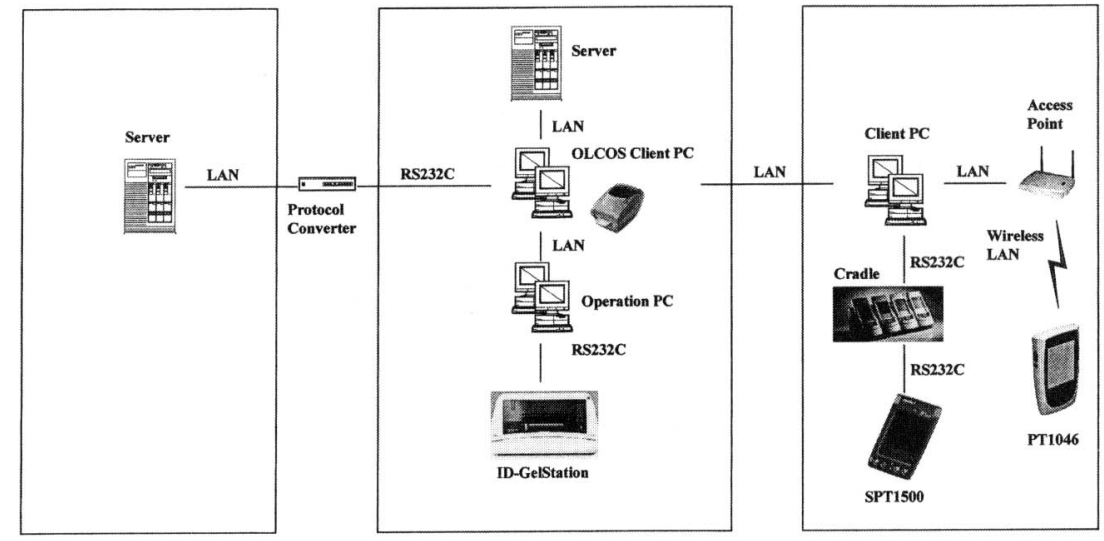

Fig. 1 Schematic representation of the blood transfusion management system and its connection with the barcode patient-blood unit identification system.

あり ${ }^{1)}$ ，不適合輸血の防止には輸血実施時の患者 照合が最も重要であることが明らかとなった。輸 血に関する医療事故やインシデントは，血液製剂 の使用単位数が増えるに従い発生頻度も増加す $ろ^{1{ }^{12)}}$. ヒューマンエラーは発生するものであると いう前提にたち，一旦発生した個々のミスを未然 に防止して患者に実害を及ぼさないシステムを組 織として導入する必要がある，バーコードを利用 した患者同定システムは, 輸血医療においても有 用であると思われる3) -5).

当順天堂大学医学部附属順天堂医院では 2000 年 4 月に医療安全対策室を設置し，医療リスクマ ネジメントに関して積極的な活動を行ってい $ろ^{6}$. 輸血医療における医療安全対策は, 輸血関連 小委員会と輸血部が連携してバーコード照合シス テム（以下，照合システム）の導入を推進した. 2001 年 1 月よりすべての入院患者を対象にバー コードを印字したリストバンドの装着を開始した が，今回照合システムと輸血管理システムおよび 自動輸血検査機器との連携を図り, 輸血マネジメ ントシステムを構築したので報告する.

\section{方法}

\section{1 病院の概要}

当院は許可病床数 1,020 床, 外来患者数 3,500 人/日, 手術件数 10,000 件/年, 赤血球製剤使用数
10,000 単位/年, 凍結血漿使用数 7,500 単位/年の 特定機能病院である. 手術部が 2 力所別棟に分か れて設置されているため, 輸血部も 2 力所に分散 して設置されている.

\section{2 ソフトウェア構成}

OLCOS 輸血システム (オリンパスシステムズ, 東京, 順天堂医院仕様) は, 病院ネットワークシ ステムの WindowsNT4.0 環境下で臨床検査シス テムと同列に構築した. 輸血サーバと病棟・手術 室のオーダリング端末，輸血部端末と自動輸血検 查機器 (ID-GelStation，オリンパス，東京)および 臨床検査システムはすべてネットワークによる接 続を行った (Fig. 1).

照合システム（ナーシングパス，オリンパスシ ステムズ)の構成を Fig. 2 に示す.ベッドサイドで 患者照合を実施するためには，予めバーコード リーダー付き携帯端末（以下，携帯端末）へ輸血 患者情報をダウンロードしておく必要がある，病 棟・外来では LAN 接続によるオーダリング端末 を介して，手術室では無線 LAN システムを介し て，輸血サーバから携带端末へ輸血患者情報をダ ウンロードする. 輸血患者情報には, 患者情報(氏 名, ID 番号, 性別, 血液型, 診療科名, 輸血予定 日）と血液製剤情報（製剂名，ロット番号，有効 期限，単位数）が含まれる. 


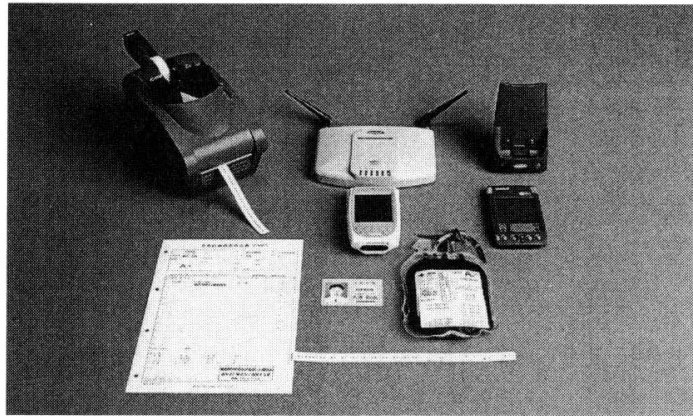

Fig. 2 Total equipment for the barcode patient-blood unit identification system, including wristband with barcode, label printer, and hand-held computer with barcode reader.

\section{3 ハードウェアの機能}

\section{(1) 輸血管理端末}

患者情報管理 (氏名, ID 番号, 生年月日, 性別, 診療科名, 担当医, 血液型, 不規則抗体の有無, 輸血歴, 自己血の有無), ハンディスキャナでの バーコード入力による血液製剤管理（入庫，割付 操作, 出庫), 検索機能 (輸血検査結果・輸血歴な どの患者情報，製剂名・血液型・採血日 - 有効期 限・照射日・在庫保有単位数などの同種血に関す る情報, 患者氏名・ID 番号・性別・血液型・診療 科名・製剤名・採血日・有効期限・使用状況など の自己血に関する情報), 輸血検查結果情報の送信 および検査結果報告書の出力，バーコード印字の 交差適合試験結果報告書と交差適合票シールの出 力, 輸血患者情報の送信, 各種デー夕集計などの 機能を有している.

\section{（2）携帯端末}

血液製剂の出庫時・受入時・実施時のバーコー ド照合，輸血患者情報の受信，輸血実施情報の送 信に機能を限定している.

\section{（3）輸血照合端末}

バーコード印字のリストバンド発行，血液製剂 の出庫部署における輸血実施情報の確認などの機 能を有している.

\section{4 運用方法}

\section{(1) 輸血検査}

オーダリング端末から輸血検査が依頼される

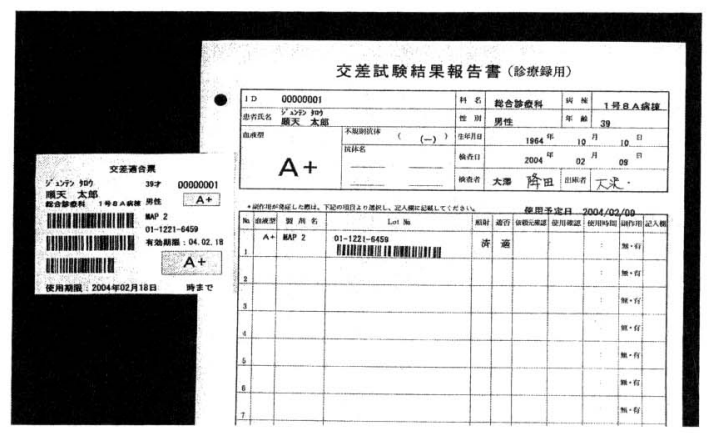

Fig. 3 Blood transfusion compatibility report form and compatibility label incorporating the patient's unique identification barcode.

と，依頼情報は臨床検査サーバにプールされる。 輸血管理端末のハンディスキャナで患者検体の バーコードを読み取り到着確認を行うと，依頼情 報が輸血サーバヘプールされる，依頼情報を自動 輸血検査機器にダウンロードし，カード法で輸血 検査を実施する，検査結果を輸血サーバへ送信す ると，輸血システムは患者の過去の検查履歴と自 動的に照合し，前回値と異なる場合は警告を画面 上に表示する。

\section{（2）血液製剤の在庫管理}

輸血管理端末のハンディスキャナで輸血用血液 製剤のバーコードを読み取ると，血液製郕に関す る情報は輸血サーバにプールされ，常に有効期限 に近い製剤からリスト表示される.

\section{（3）輸血申し込みと交差適合試験}

医師が輸血部において輸血申し込みを行う場 合,伝票に記載された患者情報が間違いないかを， 輸血管理端末で確認後に輸血申し込みを受け付け る. 血液製剂の割付操作を行い, 自動輸血検查機 器によるカード法で交差適合試験を実施して，検 査結果を輸血サーバへ送信する.

\section{（4）血液製㓮出庫時の照合}

血液製剤の出庫に際して，交差適合試験結果報 告書には製剤ロット番号のバーコードを，交差適 合票には製剤名・単位数，製剂ロット番号，有効 期限の 3 種類の情報をバーコードとして印字し出 力する (Fig. 3)。血液製剂に交差適合票を貼り付 


\section{A. 出庫時照合}

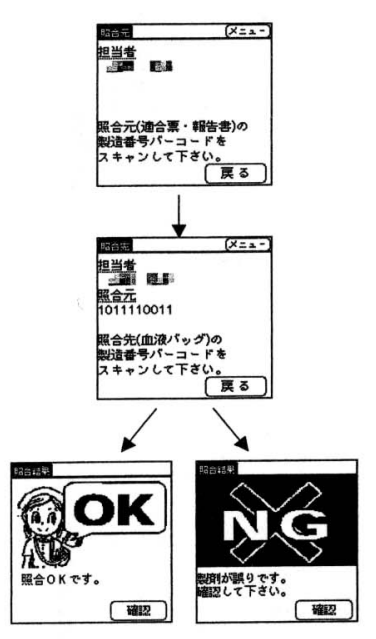

\section{B. 受入時照合}

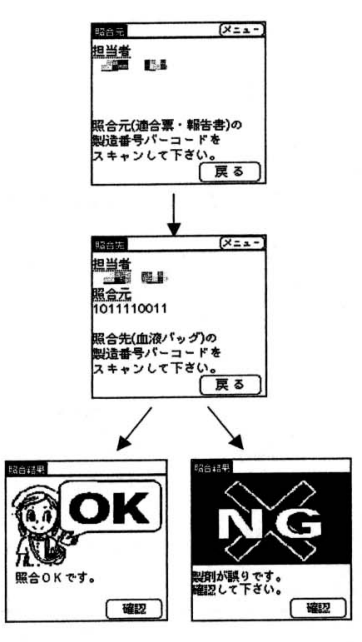

C. 実施時照合

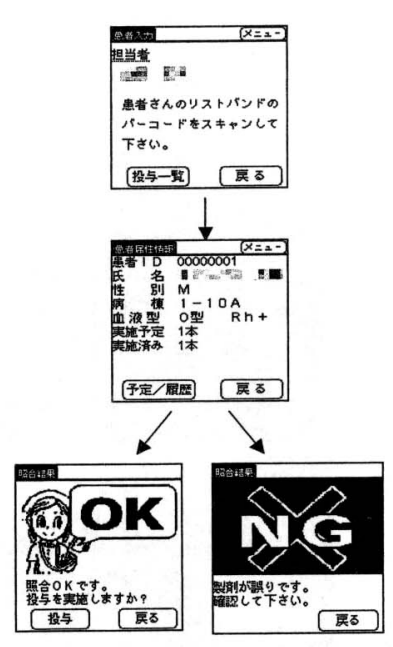

Fig. 4 Screen display of the hand-held computer during patient-blood unit identification procedures.

け，出庫担当者は携帯端末で自分のネームプレー

ト，交差適合票，製剤ロット番号のバーコードを 順に読み取り「出庫時照合」を行った後に出庫す る (Fig. 4A).

\section{（5）血液製剤受け入れ時の照合}

血液製剂が輸血実施部署に届いたら，照合実施 者は携帯端末で自分のネームプレート，交差適合 試験結果報告書，製剂ロット番号のバーコードを 順に読み取り，2 人で確認して「受入時照合」を行 う (Fig. 4B). その後, 病棟・外来ではオーダリン グ端末を介して, 手術室では無線 LANを介して, 輸血サーバから携带端末へ輸血患者情報をダウン ロードする.

（6）輸血実施時の照合

輸血実施時は，医師と看護師の 2 人が携带端末 と血液製剤をベッドサイドへ持って行き，看護師 は携帯端末で自分のネームプレート，患者リスト バンド，製剤ロット番号のバーコードを順に読み 取り，2 人で確認して「実施時照合」を行ってから 輸血を開始する (Fig. 4C).

輸血終了後, 病棟・外来ではオーダリング端末 を介して, 手術室では無線 LAN を介して, 携帯端
末から輸血サーバへ輸血実施情報(照合実施者名, 輸血実施状況）を送信する，輸血部では，輸血照 合端末のモニター画面に輸血実施情報がリスト表 示されるので(Fig. 5)，血液製剂を出庫して一定時 間未使用である場合には，輸血部から出庫部署へ 連絡して輸血実施の有無を確認する.

\section{結 果}

\section{1 手書き帳票類の廃止}

オーダリング端末による輸血検査依頼情報は, 臨床検查サーバから輸血サーバを介して自動輸血 検査機器へダウンロードされるので，手書きの検 查申込伝票と検査台帳は廃止可能となった，検査 結果報告書が自動出力されるようになったので, 過去に一度当直帯に発生した転記・記載ミスのリ スクはなくなった。

\section{2 手入力の削減}

患者検体の到着確認，血液製剂の入庫・出庫に 伴う在庫管理，輸血患者への血液製剤の割付操作 はすべてハンディスキャナによるバーコード入力 となり，輸血管理端末における手入力はほとんど 必要なくなった。また，輸血管理システムと自動 輸血検查機器を連携したことで，検查依頼情報と 


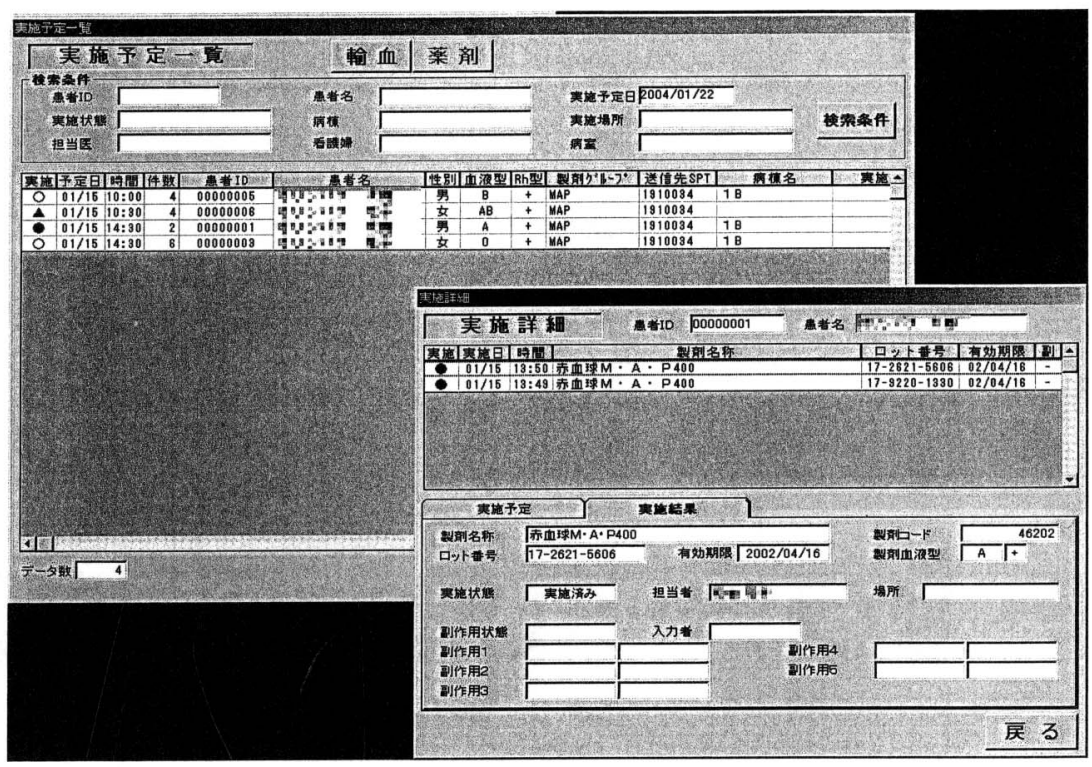

Fig. 5 Sample screen display of the verification system computer in the transfusion laboratory during real-time monitoring of the use of blood components.

検査結果出力が双方向通信で行われ，入力ミスの リスクが減少した.

\section{3 照合システムによる取り違え防止}

輸血部において「出庫時照合」を行った後に血 液製凨を出庫することで, 出庫時の取り違えを防 止することが可能となった。一方，輸血実施部署 において,「受入時照合」で届いた血液製剤と交差 適合試験結果報告書に記載されたロット番号を一 致させることにより，血液バッグの取り違えを防 止することが可能となった．更に，ベッドサイド において「実施時照合」を行うことで，患者取り 違えあるいは血液バッグの取り違えを防止するこ とが可能となった.

\section{4 輸血実施状況の確認}

輸血終了後に携帯端末から輸血実施情報を送信 すると，輸血部において輸血照合端末のモニター 画面上で輸血が実施されたことを確認出来る (Fig. 5)。従って, 輸血部では出庫した血液製剤の 輸血実施状況をリアルタイムに把握することが可 能となり，輸血実施部署における未使用血保管の リスクが減少した。

\section{考察}

当院輸血部は病院構造上の問題から 2 力所設置 されているが, 輸血部職員のマンパワーが分散さ れリスクマネジメント上リスクが高い。しかし， 現状では輸血部を 1 カ所に統合することは難しい ため, 2 力所の輸血部を有機的に運用し一元管理 する必要がある．今回，輸血管理システムを病院 ネットワークシステムに接続し, 自動輸血検査機 器と照合システムを連携させた輸血マネジメント システムを構築した. 2 力所の輸血部から同一の 輸血サーバにアクセスすることにより，患者情報 や輸血実施情報をリアルタイムに把握することが 可能となった。

患者誤認を防止する目的でリストバンドを使用 することは，輸血療法に限らずあらゆる医療行為 において有用であると思われる．特に，バーコー ドを利用した患者同定システムは不適合輸血の防 止に威力を発揮するものと期待されている ${ }^{3)}$ 5). 当院では，すべての入院患者にバーコードを印字 したリストバンドを装着し，輸血療法における患 者照合と手術室への入室時確認に使用している. 輸血の最終段階における実施時の照合は最も重要 
であるが, 輸血療法におけるヒューマンエラーは, 患者検体の採取から輸血部における輸血検査や血 液製剤の出庫，およびベッドサイドにおける輸血 実施に至るあらゆるステップにおいて発生する可 能性がある，従って，照合システムを輸血部の機 能全般とリンクさせて運用することが重要であ る.

今回，輸血マネジメントシステムを構築するに 際して，ヒューマンエラーを回避するため人手を 介するステップを可能な限り減らし電算化するこ とを試みた。転記・記載ミスを防止するため手書 きの帳票類は廃止し, 紙ベースの報告書はプリン ターからの出力とした，特に，交差適合試験結果 報告書と交差適合票はバーコードを印字して出力 することにより，血液製荗の出庫時，受入時，輸 血実施時における携帯端末での照合操作を可能に した. 照合システムを含む輸血 IT 化の目的は, 一 連の輸血業務をシステム化してヒューマンエラー を回避することにある.人的労力の削減を目的と しているわけではないので，照合システムを使用 して輸血実施時の確認を 1 人のスタッフで行うこ とを推奨するものではない.「輸血療法の実施に関 する指針」7)で示されているように, 「2人で声を出 しあって読み合わせをし」行う照合があくまでも 基本である．不適合輸血が発生した場合の迅速な 対処を想定すると，医師と看護師の 2 人による読 み合わせ確認が望ましいと思われる，照合システ ムは，目視による確認作業を更に確実にして ヒューマンエラーを回避するツール (手段・道具) と考えるべきであろう。

照合システムの最も大きな導入効果は, 輸血実 施状況をリアルタイムに把握することを可能にし た点である (Fig. 5)，血液製剤の出庫後, 輸血実施 部署において血液製剤が未使用のまま長時間保管 されることは, 不適合輸血の温床となる可能性が ある、交差適合試験結果報告書の輸血部控えが返 却される前に輸血実施状況を把握できることは, 不適合輸血の防止に繋がるものと思われる.

一連の輸血業務をシステム化した場合には，シ ステムダウン時の対応を予め取り決めておくこと が重要である，病院ネットワークシステムが定時
あるいは緊急時に停止した場合，オーダリング端 末での患者情報確認，輸血管理端末の操作，照合 システムを使用した患者照合を行うことは出来な い. システムが停止している時間帯に輸血検査か ら輸血実施までを行う場合には，マニュアルに従 い， 2 人による読み合わせ確認をより厳密に行っ て実施する必要がある，とりわけ，輸血実施に際 しては，通常でも 2 人による読み合わせ確認に付 け加える形で，携帯端末での照合操作を実施して いることから，システムダウン時においても大き な運用の変更はなく，混乱を来しにくいと思われ る.

照合システムの導入に際して, リストバンド発 行システム, 照合システム本体のソフトウェア, 携帯端末などハードウェア, 病院ネットワークシ ステムとの接続などに対して費用が発生する．照 合システムのフルパッケージを一挙に導入するに はそれ相当の導入費用が必要となってくるが，導 入費用は携帯端末の台数などハードウェアにも依 存するので，段階的に導入することが実際的であ ると思われる．先ずリストバンド発行システムを 導入して患者照合に使用し，その後輸血使用量が 多くリスクの高い手術部などへ照合システムを導 入する．医師・看護師へのシステム教育および病 院内への周知徹底を考慮しながら，徐々に導入部 署を拡大していくことが，スムーズな照合システ ムの導入に繋がるものと思われる.

（本報告の要旨は，第 50 回日本輸血学会総会， 2002 年 5 月，東京にて発表した。)

\section{文献}

1）柴田洋一, 他： $\mathrm{ABO}$ 型不適合輸血実態調查の結 果報告. 日輸血会誌, 46 (6) : 545一 $564,2000$.

2）河原和夫，他：輸血に関するインシデント事例の 検討. 日輸血会誌，49（3）：419-425, 2003.

3) Jensen, N.J., Crosson, J.T. : An automated system for bedside verification of the match between patient identification and blood unit identification. Transfusion, $36: 216-221,1996$.

4) Turner, C.L., et al. : Barcode technology : its role in increasing the safety of blood transfusion. Transfusion, $43: 1200-1209,2003$.

5）河合 健，他：ネットワークコンピュータを活用 
した院内輸血管理システム. 日輸血会誌, $47(3)$ ： $369-377,2001$.

6) 梁井 盿, 大坂顯通編：実践医療リスクマネジメ ント, ビほう，東京， 2003.
7）輸血療法の実施に関する指針，血液製剤調查機構 編，血液製剤の使用にあたって，第 2 版，薬業時 報社，東京，1999, 33-46. 